\title{
A Proposed Program to Improve Quality of life for the Orphans at Social Care Homes
}

\author{
Manal M. Alqahtani \\ Assistant Professor of Social Work, \\ College of Social Work, \\ Princess Nourah Bint Abdulrahman University, \\ Airport Road, King Khalid International Airport, \\ Riyadh 11564, Saudi Arabia
}

DOI: https://doi.org/10.36941/jesr-2021-0023

\section{Abstract}

The present paper investigates the reality of services and quality of life of orphans, identifies the relationship between both variables, and proposes a program to improve the quality of life among the orphans at social care homes. The author developed and applied a questionnaire of the reality of services provided and a scale of quality of life to (100) orphans at social care homes in Riyadh, Saudi Arabia. The results showed low levels of services and quality of life among the orphans at social care homes. There was a positive correlation between those services and the quality of life among orphans. The paper recommends the adoption of the proposed program by decision-makers and specialists in the care and rehabilitation of the orphans to improve their quality of life. Moreover, the program should be an integral part of rehabilitation and education programs delivered to the orphans in the future.

Keywords: Quality of life, Orphans, Proposed program, Social care homes

\section{Introduction}

Family is the foundation of the community. It affects the child and provides the language, culture, customs, values, and attitudes of the community. It provides care as well as material, psychological, and social. Moreover, it reinforces the child's personality to handle life stress and problems and become active and productive. It gives the child behavioral and social skills to establish a proper social relationship and achieve psychological stability. However, a child may live in social care homes if one or both parents die (UNICEF, 2004). The child's relationship with his family has a major impact on personal development. However, the imbalance of the family triangle (i.e. father, mother, and children) often creates psychological disorders among children. Furthermore, failure to satisfy the child's needs develops behavioral problems as a reaction to the lack of security and belonging in the form of withdrawal or aggressive responses (Al-Qamsh \& Al-Imam, 2006; Al-Rashid \& Al-Dhahyan, 2006; Boutros, 2007).

Orphanhood is a critical stage for children who have lost family support. Al-Baz (2012) indicates that deprivation of family care greatly affects the child's personality, even after growing up because the loss of both parents or one of them creates a frightened, aggressive, reluctant, as well as less competitive 
and creative person. Johns and Ramidas (2004) report that children deprived of parental care suffer more behavioral, emotional, health, and academic problems. Islih (2000) asserts that a parent's death affects the personality traits of children in terms of psychological adjustment and self-concept because of family disintegration that causes painful experiences, insecurity, and sadness. These experiences cause psychological maladjustment, bad self-concept, tension, concern, and misery. Orphans often encounter a lack of social appreciation and belonging that result in stress. Strain theory considers that stressful life events and changes suggest that loss predicts behavioral problems and academic maladjustment.

Orphans in social care homes never experience integration within the community. They have to adhere to the rules and regulations of the house. Thus, they feel lonely and isolated. They lack the requirements of growth, such as love, affection, security, psychological stability, belonging, freedom, privacy, independence, and acquisition of new experiences. Unless they get proper upbringing, they take revenge on their reality and community, represented in isolation, non-interaction, and crime (AlFaqihi, 2006; Al-Shareef, 2002; Halima, 2013). Moreover, orphans show symptoms of confusion, frustration, anxiety, depression, and behavioral disorders, such as rebellion or disobedience, which may negatively affect their academic achievement. They show anger and hatred towards the community and often tend to suicide. Failure of care providers, either at these institutions or at school, maximizes the child's psychological problems (Foster \& Williamson, 2000; Harman, Childs, and Kelleher, 200o; Taylor \& Carlson, 2004; Witt and Lessing, 2005).

Although Ibrahim (2009) contends that the methods of care and the quality of services provided to orphans at care homes form personality, Al-Attas (2012) reports that orphans residing at care homes suffer higher psychological insecurity. UNICEF (2006) indicates that orphans are more vulnerable to protection violations. No institution could replace the family (Foster \& Williamson, 2000). Some studies report a direct correlation between children's upbringing at care homes and their psychological disorders. Orphans tend to personalize problems and have various psychological problems, such as loneliness, anxiety, low self-esteem, drop out of the university, unemployment, homelessness, and drug addiction (Al-Attas, 2012; Al-Suwaihri, 2010; Al-Thumairy, 2011; Barn, Andrew, and Mantovani, 2005; Casares, Thombs, and Rousseau, 2004; Foster \& Williamson, 2000; Ibrahim, 2009; Jumaa, 2011; Kafi, 2012; McMillan, 2003; Obaid, 2013; Stein, 2006). The community and institutions should help the orphans overcome their problems through developing programs that provide them with proper concepts, experiences, attitudes, and habits to adapt to their community psychologically, socially, economically, and culturally (Al-Dakhakhni, 2007).

In Saudi Arabia, the orphans are raised and kept at social care homes to avoid loss and deviation in case of parents' death, having no relatives, or family disintegration and divorce. However, Al-Hajjaji (2013) and Al-Sahli (2011) state that these efforts are insufficient because the concern is given to the material and recreational aspects. Muhammad (2017) demonstrates that the services delivered at care homes and orphanages are inappropriate. They do not satisfy the minimum requirements of the orphans and cause various problems, including anxiety, poor personal and social adjustment, and low self-esteem. The author claims that the family establishes a normal social environment and provides quality of life (QOL) for children. However, loss of family care and living at care homes expose children to behavioral, emotional, social, educational, and physical disorders.

Because the orphans represent an important category in the Saudi community, their QOL should be improved to overcome troubles and pressures. QOL is an important principle in positive psychology that focuses on positive aspects, e.g. positive feelings, happiness, optimism, self-satisfaction, and good life (Seligman, 2002). It denotes the positive sense, self-satisfaction, constant attempt to achieve significant personal goals that help enjoy autonomy, as well as positive and reciprocal social relations. It is also associated with the general sense of happiness, tranquility, and reassurance (Mashri, 2014). QOL reflects mental health, satisfaction with the various services, prevalence of love and optimism, positivity, high morale, belonging, and loyalty (Mansi, 2010). It involves three aspects: obtaining life fundamentals, satisfaction with life aspects, and achieving high levels of personal pleasure and accomplishments (Omar, 2008). Al-Rassi (2006) states that QOL is a multidimensional concept that is 
associated with psychological, social, spiritual, physical, and mental needs. According to Mustafa and Youssef (2018), it involves physical, mental, psychological, and social aspects. QOL indicates persons' awareness of the quality of the material and social services to satisfy their material and social needs. It involves well-being, life satisfaction, delight, and adopting community virtues. Moreover, it helps achieve ambitions and interests, overcome life problems, and define personal goals (Abu Hammad, 2019; Al-Obaidi, 2013).

Kapka, Baumann, Anota, and Buron (2013) identified the relationship between optimism, anxiety, and QOL. The results showed a correlation between anxiety and QOL. Al-Dulaimi and Hassan (2012) identified the relationship between self-esteem and QOL. The results manifested a correlation between self-esteem and QOL among students at University of Babylon. Bakr (2011) showed the possibility of predicting QOL through social belonging and social acceptance. Al-Maliki (2011) explored the relationship between depression and personal meaning, on the one hand, and QOL, on the other, among the students of the College of Education at Umm Al-Qura University. The results illustrated a significant positive correlation between the personal meaning of QOL and a negative correlation between QOL and depression. Baumann et al. (2011) reported that the correlation between QOL and learning skills increases job opportunities for graduates at colleges offering specialized applied vocational courses.

Because of the importance of the concept of QOL and its improvement, it has been addressed by multiple authors. For example, Al-Dahni (2018), Al-Hussainat (2015), Eid (2018), Fenandez and Rocha (2009), Gamal (2016), Hamed (2018), Mahmoud (2016), Mustafa and Youssef (2018), and Shokair (2010) asserted its importance in identifying many other relevant variables and its impact on the one's various aspects. Abdelhamid (2018), Abu Shanab (2017), Ali (2017), Badr (2019), Damiry (2019), Mousa (2016), and Zidan (2015) recommended conducting cognitive counseling programs to improve QOL. AlHuwairini (2018) argued that QOL is one of the most important programs to achieve the Saudi Vision 2030 that stresses improving the lifestyle of the person and the family. Salami and Jaloul (2017) identified some practical measures related to the orphan's QOL to achieve a balanced psychological, social, and academic life, as well as more positive adjustment.

The orphan who enjoys QOL easily overcomes difficulties, pressures, and problems. Therefore, giving concern about the orphans' QOL is extremely important. To face life challenges and their concerns, they should take advantage of their capabilities, energies, and potentials to maximize effectiveness, satisfaction, happiness, life orientation, hope, optimism, and positivity. Many authors attempted to measure the person's conception of QOL and to define its major elements. For instance, Salem (2001) reported that happiness increase through training in managing projects and time. Hamed (2018) stated that a person can achieve QOL through the awareness of the need for development and organizing the achievement of goals. According to Lwasaki (2007), the mechanisms that improve QOL include positive emotions, high self-esteem, social and cultural connections, learning and human development, and searching for life concept.

Muhammad (2017) identified the effectiveness of logotherapy in developing a sense of QOL among orphan adolescents aged 14-18 years in care homes. The author adopted the QOL scale, life concept scale, and a logotherapy program to develop QOL. Borzak and Shalali (2017) identified QOL among orphan adolescents and applied the QOL scale to (6o) $2^{\text {nd }}$ - grade secondary students. The results revealed a difference in QOL domains according to their effect on the participants. Ali (2016) designed and investigated the effectiveness of a program in developing emotional intelligence skills and its impact on the quality of life among (136) orphan adolescents in social care homes. The study adopted an emotional intelligence scale, QOL scale, and an emotional intelligence development program. The results showed the effectiveness of the program in developing emotional intelligence skills that affect QOL.

Naimat (2016) identified the level of stress among (102) orphans in Aqaba Governorate and its relationship to both psychological hardiness and QOL. Three scales (i.e. stress scale, QOL scale, and psychological hardiness scale) were developed. The results indicated that the stress level among the participants was moderate. While the (emotional) domain was ranked first and high, the 
(physiological) domain was ranked second and moderate. There was a statistically significant negative relationship between stress and its domains, on the one hand, and psychological hardiness and its domains as well as QOL and its domains, on the other.

Sabri (2015) identified the reality of QOL among (45) orphans aged 14-16 years living in care homes, using the Beck Depression Inventory, QOL scale, and stress scale. The results exhibited statistically significant differences in the mean scores of QOL due to depression and stress. Khamis (2013) identified QOL and its relationship to some characteristics of social behavior and orphans and those with parents in the Kingdom of Bahrain. The results illustrated a statistically significant correlation between QOL and some characteristics of positive social behavior among the orphans. Moreover, there were statistically significant differences between the orphans and those with parents in QOL in favor of those with parents.

Abu Rasin (2012), Ahmed and Hussein (2009), Al-Birri (2015), Al-Dabour and Zahran (2013), Ali (2012), Aljawalda (2013), Break (2016), Habib (2016), Khalil (2013), Oghnia, Al-Alfi, and Abdelhadi (2012), Ramadan (2014), and Selim (2015) addressed training, counseling, cognitive, and behavioral programs to improve QOL among different social categories. Accordingly, the author could define the content of the proposed program, activities, and strategies to improve the social, psychological, cultural, educational, academic, and health domains of QOL among the orphans. Based on her experience in psychology and mental health, the author observed that orphans with low QOL are less effective and encounter psychological and social pressures and low achievement. The author argues that providing the orphans with counseling and training programs helps reduce stress and improve QOL. They demonstrate self-adjustment, integrate into the community, develop abilities, regain self-confidence, and satisfy psychological needs. Pekmezovic, Popovic, Tepavcevic, Gazibara, and Paunic (2011) indicated that counseling and training programs helped the participants better understand QOL by utilizing all services and participating in some systematic and beneficial activities. Hence, the present paper aims to provide a proposed program to improve the orphans' QOL at social care homes.

\section{Methodology}

The paper adopted the descriptive analytical approach. The author attempted to identify the reality of services provided to the orphans, define their QOL at social care homes, and investigate the relationship between the services provided to them and QOL. Additionally, a proposed program was proposed to improve QOL among orphans at social care homes.

\subsection{Population}

The population comprised (10o) orphans at three social care homes (Education House for Girls in Ad Diriyah, Nursery House in Ulaysha, and Rabwa villas House) in Riyadh, Saudi Arabia during the second semester of the academic year 2019/2020. They are aged (14) to (19) years.

\subsection{Sampling}

The sample involved (27) orphans living three social care homes (Education House for Girls in Ad Diriyah, Nursery House in Ulaysha, and Rabwa Villas House) in Riyadh, Saudi Arabia.

Table (1): Distribution of the sample

\begin{tabular}{|l|l|c|c|}
\hline Variables & Frequency & Percentage \\
\hline \multirow{4}{*}{ Age } & From (11) to less than (14) & 0 & $0 \%$ \\
\cline { 2 - 4 } & From (14) to less than (17) & 19 & $70.4 \%$ \\
\cline { 2 - 4 } & From (17) to less than (20) & 8 & $29.6 \%$ \\
\cline { 2 - 4 } & From (20) to (23) & 0 & $0 \%$ \\
\cline { 2 - 4 } & Total & 27 & $100 \%$ \\
\hline
\end{tabular}




\begin{tabular}{|c|c|c|c|}
\hline \multicolumn{2}{|l|}{ Variables } & Frequency & Percentage \\
\hline \multirow{5}{*}{ Education } & Primary & $\mathrm{o}$ & $\mathrm{o} \%$ \\
\hline & Middle & 9 & $33.3 \%$ \\
\hline & Secondary & 16 & $59 \cdot 3 \%$ \\
\hline & University & 2 & $7.4 \%$ \\
\hline & Total & 27 & $100 \%$ \\
\hline \multirow{4}{*}{ Missing Person } & Father and Mother & 27 & $100 \%$ \\
\hline & Father & o & $\mathrm{o} \%$ \\
\hline & Mother & $\mathrm{O}$ & $\mathrm{O} \%$ \\
\hline & Total & 27 & $100 \%$ \\
\hline
\end{tabular}

\subsection{Tools}

\subsubsection{Questionnaire}

The questionnaire aimed to identify the reality of services provided to the orphans at social care homes. The author reviewed the relevant literature and identified the domains and items of the questionnaire. The preliminary form comprised (39) items distributed to (5) domains. It was reviewed by (11) Saudi faculty members specialized in social work and orphans' care. According to their views, some items were omitted, added, or modified. The final form was divided into two sections. While section one involved the orphan's personal data (age, educational level, and the missing person), section two comprised (39) items distributed to (5) domains, namely social and economic care (9 items); psychological care ( 7 items); cultural, recreational, and sports care ( 8 items); educational care ( 7 items); health and physical care (8 items).

It was corrected using the Five-point Likert scale, as shown in Table (2).

Table (2): Five-point Likert scale.

\begin{tabular}{|c|c|c|c|c|c|}
\hline Agreement & Strongly Agree & Agree & Undecided & Disagree & Strongly Disagree \\
\hline Score & 5 & 4 & 3 & 2 & 1 \\
\hline
\end{tabular}

To verify its validity, the questionnaire was reviewed by (11) Saudi faculty members specialized in social work and orphans' care to evaluate the appropriateness, relevance, clarity, and wordiness of the items. According to their views, some items were omitted and modified to have the final form of the questionnaire. The internal validity was estimated between each domain and the total score of the pilot sample that comprised (10) orphans.

Table (3): Correlation coefficients between each domain and the total score

\begin{tabular}{|l|c|}
\hline Social and economic care \\
\hline Correlation coefficient \\
\hline Psychological care & \multicolumn{2}{|l|}{$0.95^{* *}$} \\
\hline Correlation coefficient & $0.96^{* *}$ \\
\hline Cultural, recreational, and sports care & $0.98^{* *}$ \\
\hline Correlation coefficient & \\
\hline Educational care & $0.99^{* *}$ \\
\hline Correlation coefficient & \\
\hline Health and physical care & $0.95^{* *}$ \\
\hline Correlation coefficient & \\
\hline
\end{tabular}

${ }^{* *}$ Significant at the level of (o.o1)

Table (3) shows that the correlation coefficients ranged from (0.95) to (0.99). Thus, they are statically 
significant at the level of (o.o1), and the questionnaire is valid.

The questionnaire's reliability was estimated using Cronbach's equation.

Table (4): Values of the questionnaire's reliability

\begin{tabular}{|l|c|}
\hline Tool & Cronbach's Alpha coefficient \\
\hline First domain & $0.95^{* *}$ \\
\hline Second domain & $0.96^{* *}$ \\
\hline Third domain & $0.97^{* *}$ \\
\hline Fourth domain & $0.96^{* *}$ \\
\hline Fifth domain & $0.98^{* *}$ \\
\hline
\end{tabular}

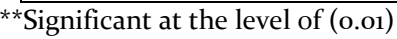

Table (4) indicates that all reliability coefficients of the questionnaire and its domains are significant at the level of (o.o1). Hence, the questionnaire is highly reliable.

\subsubsection{Quality of life scale}

The scale aimed to identify the level of QOL among the orphans at social care homes. The author reviewed some relevant psychological scales, such as QOL scales of Abu Halawa (2010), Ahmed (2008), Al-King (2014), Mahmoud and Al-Jammali (2010), and Mansi and Kadhim (2006). The author defined the domains and items of the scale. The preliminary form comprised (46) items distributed to (5) domains. The scale was reviewed by (11) Saudi faculty members specialized in social work and orphans' care. According to their views, some items were omitted, added, or modified. The final form was divided into two sections while section one involved the orphan's personal data (age, educational level, and the missing person), section two comprised (46) items distributed to (5) domains: Quality of social life (10) items, quality of psychological life (10) items, quality of cultural life and time management (7) items, quality of educational life (9) items, and quality of health life (10) items.

Table (5): Domains and items of QOL scale

\begin{tabular}{|c|l|c|c|c|}
\hline No. & Domain & Positive items & Negative items & Total \\
\hline 1 & Social & $\mathbf{1 , 2 , 4 , 5 , 6 , 7 , 9 , 1 0}$ & 3,8 & 10 \\
\hline 2 & Psychological & $\mathbf{1 1 , 1 2 , 1 4 , 1 8 , 2 0}$ & $13,15,16,17,19$ & 10 \\
\hline 3 & Cultural \&time management & $\mathbf{2 2 , 2 3 , 2 4 , 2 7}$ & $\mathbf{2 1 , 2 5 , 2 6}$ & 7 \\
\hline 4 & Education & $\mathbf{2 8 , 3 1 , 3 2 , 3 3 , 3 4 , 3 5 , 3 6}$ & $\mathbf{2 9 , 3 0}$ & 9 \\
\hline 5 & Health & $37,38,39,41,42,43,45,46$ & 40,44 & 10 \\
\hline Total & 32 & 14 & 46 \\
\hline
\end{tabular}

Scores were estimated and a Five-point Likert scale ( strongly agree, agree, slightly agree, disagree, and strongly disagree) was used for the answer. While the maximum score was (230), the minimum score was (46), positive items were (32), and the negative items were (14), where the score was inversely estimated.

To verify its validity, the scale was reviewed by (11) Saudi faculty members specialized in social work and orphans' care to evaluate the appropriateness, relevance, clarity, and wordiness of the items. According to their views, some items were omitted and modified to have the final form. It was asserted that the scale and its domains measure the orphans' QOL. The internal validity was estimated between the score of each domain and the total score of the pilot sample that comprised (10) orphans. 
Table (6): Correlation coefficients between the score of the domains and the total score

\begin{tabular}{|l|c|}
\hline Quality of social life & $0.70^{* *}$ \\
\hline Correlation coefficient & $0.66^{* *}$ \\
\hline Quality of psychological life & $0.53^{* *}$ \\
\hline Correlation coefficient & \\
\hline Quality of cultural life and time management & $0.46^{* *}$ \\
\hline Correlation coefficient & \\
\hline Quality of educational life & $0.72^{* *}$ \\
\hline Correlation coefficient & \multicolumn{2}{|l}{} \\
\hline Quality of health life &
\end{tabular}

**Significant at the level of (o.o1)

Table (6) indicates that correlation coefficients ranged from (0.46) to (0.72). Thus, they are statically significant at the level of (o.o1), and the scale is valid. The reliability was estimated using Cronbach's equation.

Table (7): Values of the scale's reliability

\begin{tabular}{|l|c|}
\hline Tool & Cronbach's alpha \\
\hline First domain & $0.73^{* *}$ \\
\hline Second domain & $0.71^{* *}$ \\
\hline Third domain & $0.69^{* *}$ \\
\hline Fourth domain & $0.68^{* *}$ \\
\hline Fifth domain & $0.68^{* *}$ \\
\hline
\end{tabular}

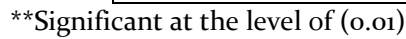

Table (7) indicates that all reliability coefficients of the scale and its domains are significant at the level of (o.o1), so the scale is highly reliable.

\section{Results And Discussion}

To answer the $1^{\text {st }}$ question, frequencies, relative weight, and percentages of the responses were estimated.

Table (8): Responses to the reality of services provided to the orphans at social care homes

\begin{tabular}{|c|c|c|c|c|c|c|c|c|c|c|}
\hline \multirow{3}{*}{ 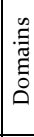 } & \multirow{3}{*}{ Item } & \multicolumn{9}{|c|}{ Total sample } \\
\hline & & \multicolumn{5}{|c|}{ Frequency } & \multirow[b]{2}{*}{$\begin{array}{c}\text { Relative } \\
\text { weight }\end{array}$} & \multirow[b]{2}{*}{$\%$} & \multirow[b]{2}{*}{ Rank } & \multirow[b]{2}{*}{ Mear } \\
\hline & & $\begin{array}{c}\text { Strongly } \\
\text { agree }\end{array}$ & agree & Undecided & Disagree & $\begin{array}{l}\text { Strongly } \\
\text { disagree }\end{array}$ & & & & \\
\hline \multirow{9}{*}{ 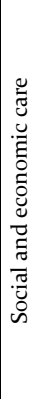 } & $\begin{array}{l}\text { Enhance the orphans' relationships with families and } \\
\text { relatives through mutual visits }\end{array}$ & 4 & 6 & $\mathrm{o}$ & 4 & 13 & 65 & 48.14 & 6 & \multirow{9}{*}{54.72} \\
\hline & Provide housing, clothing, and basic needs for the orphans. & 6 & 6 & $\mathrm{o}$ & 3 & 12 & 72 & 53.33 & 5 & \\
\hline & Provide appropriate vocational training for the orphans. & 3 & 9 & 1 & 12 & 2 & 80 & 59.25 & 1 & \\
\hline & $\begin{array}{l}\text { Engage the orphans in the programs of a social club at the } \\
\text { house. }\end{array}$ & 3 & 8 & 2 & 11 & 3 & 78 & $57 \cdot 77$ & 3 & \\
\hline & $\begin{array}{l}\text { Engage the orphans in external kindergartens to get involved } \\
\text { with others and develop their abilities and potentials }\end{array}$ & 6 & 4 & 6 & 1 & 10 & 76 & 56.29 & 4 & \\
\hline & $\begin{array}{l}\text { Provide the orphans with grooms and supervise their } \\
\text { marriage }\end{array}$ & 3 & 3 & 7 & 1 & 13 & 63 & 46.66 & 7 & \\
\hline & Provide a constant social worker at the house. & 9 & 3 & 1 & 2 & 12 & 76 & 56.29 & 4 & \\
\hline & $\begin{array}{l}\text { Cooperate with organizations, charities, and voluntary } \\
\text { bodies to fulfill their role towards the orphans }\end{array}$ & 7 & 4 & 3 & 3 & 10 & 76 & 56.29 & 4 & \\
\hline & Provide the orphans with school fees & 9 & 4 & 1 & 2 & 11 & 79 & 58.51 & 2 & \\
\hline
\end{tabular}




\begin{tabular}{|c|c|c|c|c|c|c|c|c|c|c|}
\hline \multirow{7}{*}{ 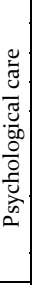 } & Encourage the orphans to discuss their personal issues & 5 & 4 & 1 & 4 & 13 & 65 & 48.14 & 4 & \multirow{7}{*}{50} \\
\hline & Reward high achievers & 8 & 3 & 1 & 2 & 13 & 72 & 53.33 & 2 & \\
\hline & Encourage the orphans to practice hobbies & 6 & 6 & 1 & 2 & 12 & 73 & 54.07 & 1 & \\
\hline & Provide psychological counseling for the orphans & 6 & 4 & 2 & 1 & 14 & 68 & 50.37 & 3 & \\
\hline & $\begin{array}{l}\text { Develop therapeutic counseling programs for the orphans to } \\
\text { treat the behavioral problems and mental disorders } \\
\text { resulting from the lack of parental care }\end{array}$ & 5 & 3 & 1 & 2 & 16 & 60 & 44.44 & 6 & \\
\hline & $\begin{array}{l}\text { Develop psychological counseling programs to support the } \\
\text { orphans professionally. }\end{array}$ & 3 & 6 & 1 & 4 & 13 & 63 & 46.66 & 5 & \\
\hline & Constant presence of a psychologist at the house & 6 & 6 & 1 & 1 & 13 & 72 & 53.33 & 2 & \\
\hline \multirow{8}{*}{ 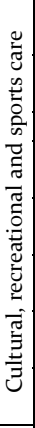 } & $\begin{array}{l}\text { Arrange recreational camps and trips to establish good } \\
\text { relations among the orphans }\end{array}$ & 6 & 3 & 11 & 4 & 3 & 86 & 63.70 & 4 & \multirow{8}{*}{62.49} \\
\hline & $\begin{array}{l}\text { Visit recreational and commercial centers as well as art and } \\
\text { cultural exhibitions }\end{array}$ & 8 & 2 & 11 & 2 & 3 & 88 & 65.18 & 2 & \\
\hline & Visit the home's library and public libraries & 5 & 3 & 12 & 2 & 5 & 82 & 60.74 & 5 & \\
\hline & $\begin{array}{l}\text { Activate parts of libraries, e.g. the audio and the visual } \\
\text { library }\end{array}$ & 2 & 3 & 13 & 6 & 3 & 76 & 56.29 & 6 & \\
\hline & $\begin{array}{l}\text { Arrange cultural competitions in the curricula, general } \\
\text { sciences, arts, and religious information }\end{array}$ & 1 & 8 & 4 & 11 & 3 & 74 & 54.81 & 7 & \\
\hline & $\begin{array}{l}\text { Engage the orphans in matches, tournaments, and sports } \\
\text { competitions inside and outside the home }\end{array}$ & 6 & 3 & 11 & 5 & 2 & 87 & 64.44 & 3 & \\
\hline & $\begin{array}{l}\text { Cultivate the orphans' abilities and discover their tendencies } \\
\text { through artwork practice }\end{array}$ & 7 & 4 & 11 & 2 & 3 & 91 & 67.40 & 1 & \\
\hline & $\begin{array}{l}\text { Provide sports equipment to encourage the orphans to } \\
\text { practice inside the home }\end{array}$ & 8 & 1 & 12 & 5 & 1 & 91 & 67.40 & 1 & \\
\hline \multirow{7}{*}{ 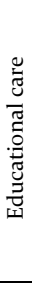 } & $\begin{array}{l}\text { Enroll the orphans at schools and follow their academic } \\
\text { achievement }\end{array}$ & 4 & 3 & 7 & 10 & 1 & 74 & 54.81 & 5 & \multirow{7}{*}{$57 \cdot 35$} \\
\hline & Designate the orphans' places at the university & 4 & 2 & 8 & 10 & 3 & 75 & 55.55 & 4 & \\
\hline & Develop a program for the orphans' study at the house & 5 & 1 & 10 & 9 & 2 & 79 & 58.51 & 3 & \\
\hline & $\begin{array}{l}\text { Solve the problems that may hinder the orphans' academic } \\
\text { achievement }\end{array}$ & 2 & 2 & 8 & 10 & 5 & 67 & 49.62 & 6 & \\
\hline & Provide the orphans with educational materials and books & 6 & 3 & 9 & 5 & 4 & 83 & 61.48 & 1 & \\
\hline & $\begin{array}{l}\text { Form specialized committees for managing Qur'an } \\
\text { memorization and encouraging the orphans to join }\end{array}$ & 5 & 4 & 11 & 2 & 5 & 83 & 61.48 & 1 & \\
\hline & Provide computer courses for the orphans & 5 & 3 & 9 & 7 & 3 & 81 & 60 & 2 & \\
\hline \multirow{8}{*}{ 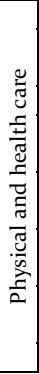 } & Periodic preventive medical examination for the orphans & 6 & 1 & 9 & 9 & 2 & 81 & 60 & 4 & \multirow{8}{*}{61.2} \\
\hline & $\begin{array}{l}\text { Provide integrated medical and treatment services for the } \\
\text { orphans under medical supervision }\end{array}$ & 5 & 3 & 8 & 9 & 2 & 81 & 60 & 4 & \\
\hline & Provide necessary medicines for the orphans & 5 & 1 & 10 & 9 & 2 & 79 & 58.51 & 5 & \\
\hline & $\begin{array}{l}\text { Comprehensive immunization of the orphans against } \\
\text { infectious diseases }\end{array}$ & 6 & 2 & 9 & 8 & 2 & 83 & 61.48 & 3 & \\
\hline & $\begin{array}{l}\text { The orphans' health education as a fundamental for } \\
\text { controlling health problems }\end{array}$ & 4 & 2 & 10 & 8 & 3 & 77 & 57.03 & 6 & \\
\hline & $\begin{array}{l}\text { Coordinate with medical centers to deliver awareness- } \\
\text { raising and guidance lectures }\end{array}$ & 7 & 3 & 8 & 6 & 3 & 86 & 63.70 & 2 & \\
\hline & $\begin{array}{l}\text { Provide proper food and nutrition according to health } \\
\text { standards and under medical supervision }\end{array}$ & 6 & 4 & 10 & 4 & 3 & 87 & 64.44 & 1 & \\
\hline & Familiarize the orphans with hygiene and sanitation & 6 & 4 & 10 & 4 & 3 & 87 & 64.44 & 1 & \\
\hline \multicolumn{7}{|c|}{ Total } & 3016 & 57.28 & & \\
\hline
\end{tabular}

Table (8) shows that the total score (57.28\%) and the mean scores of the domains reflect the low level of services provided to the orphans at social care homes that are dissatisfactory from the participants' perspective. While "psychological care services" was ranked the lowest with a mean of (50\%), "cultural, recreational, and sports care" was ranked first with a mean of (62.49\%). The author attributes this finding to the lack of competent counselors and counseling programs. Attention is given to recreational and sports aspects rather than the psychological and social ones despite their importance. The orphans also lack social adjustment and communication and encounter various obstacles. Hence, they undergo emotional instability and anxiety, especially with the prevalence of social and economic fluctuations. This result is consistent with Al-Hajjaji (2013), Al-Sahli (2011), and Muhammad (2017) that showed the low level of services and care provided at social care homes and social institutions.

To answer the $2^{\text {nd }}$ question, frequencies, relative weight, and percentages of the participants' responses to the level of QOL for the orphans at social care homes were estimated. 
Table (9): The participants' responses to the level of QOL for the orphans at social care homes

\begin{tabular}{|c|c|c|c|c|c|c|c|c|c|c|}
\hline \multirow[b]{3}{*}{$\stackrel{\circ}{\circ}$} & \multirow{3}{*}{ Items } & \multicolumn{9}{|c|}{ Total sample } \\
\hline & & \multicolumn{5}{|c|}{ Frequency } & \multirow[b]{2}{*}{$\begin{array}{l}\text { Relative } \\
\text { weight }\end{array}$} & \multirow{2}{*}{$\%$} & \multirow{2}{*}{ Rank } & \multirow{2}{*}{ Mean } \\
\hline & & $\begin{array}{c}\text { Strongly } \\
\text { agree }\end{array}$ & agree & Undecided & Disagree & $\begin{array}{l}\text { Strongly } \\
\text { disagree }\end{array}$ & & & & \\
\hline \multirow{10}{*}{ 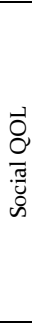 } & I can positively influence others' life. & 5 & 3 & 3 & 6 & 10 & 68 & 50.37 & 6 & \multirow{10}{*}{51.77} \\
\hline & I enjoy my free time with others. & 1 & 5 & 7 & 10 & 4 & 70 & 51.85 & 4 & \\
\hline & I find it difficult to deal with others. & 3 & 3 & 4 & 13 & 4 & 69 & 51.11 & 5 & \\
\hline & I benefit from others' life experiences. & 4 & 3 & 5 & 10 & 5 & 72 & $53 \cdot 33$ & 3 & \\
\hline & I am satisfied with the way I treat others. & 4 & 5 & 4 & 8 & 6 & 74 & 54.81 & 2 & \\
\hline & $\begin{array}{l}\text { I accept others' ideas even if they are inconsistent with } \\
\text { mine. }\end{array}$ & 4 & 4 & 5 & 3 & 11 & 68 & 50.37 & 6 & \\
\hline & I enjoy talking to others. & 4 & 4 & 5 & 10 & 4 & 75 & 55.55 & 1 & \\
\hline & I act in a manner that does not fit my social norms. & 3 & 2 & 5 & 11 & 6 & 66 & 48.88 & 7 & \\
\hline & People respect and appreciate me. & 4 & 5 & 5 & 4 & 9 & 72 & 53.33 & 3 & \\
\hline & My friends always support me though I am an orphan. & 4 & 3 & 3 & 7 & 10 & 65 & 48.14 & 8 & \\
\hline \multirow{10}{*}{ 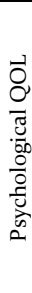 } & I can control my emotions. & 4 & 3 & 2 & 7 & 11 & 63 & 46.66 & 3 & \multirow{10}{*}{44.73} \\
\hline & I feel happy at the home. & 2 & 2 & 5 & 10 & 8 & 61 & 45.18 & 4 & \\
\hline & I feel very sad when I remember my reality as an orphan. & 3 & 1 & 4 & 8 & 11 & 58 & 42.96 & 5 & \\
\hline & I feel proud of myself. & 4 & 3 & 6 & 10 & 4 & 74 & 54.81 & 1 & \\
\hline & I feel disappointed about my accomplishments in life. & 1 & 3 & 8 & 7 & 8 & 63 & 46.66 & 3 & \\
\hline & I shed tears when I think about my future. & 1 & 3 & 2 & 10 & 11 & 54 & 40 & 7 & \\
\hline & I feel alone. & 2 & 1 & 4 & 11 & 9 & 57 & 42.22 & 6 & \\
\hline & I peacefully think about my life issues. & 3 & 2 & 7 & 5 & 10 & 64 & 47.40 & 2 & \\
\hline & I feel inferior because I am an orphan. & 1 & 4 & 2 & 9 & 11 & 56 & 41.48 & & \\
\hline & I find my life stable despite my circumstances. & 1 & 2 & 3 & 11 & 10 & 54 & 40 & 7 & \\
\hline \multirow{7}{*}{ 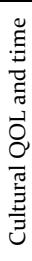 } & I have no time to let off some steam. & 5 & 5 & 7 & 8 & 2 & 84 & 62.22 & 4 & \multirow{7}{*}{63.91} \\
\hline & Practicing my hobbies makes me delighted. & 5 & 7 & 5 & 3 & 3 & 77 & 57.03 & 6 & \\
\hline & I am satisfied with the way I spend my free time. & 3 & 8 & 10 & 3 & 3 & 86 & 63.70 & 3 & \\
\hline & \begin{tabular}{|l|} 
I fulfill tasks on time. \\
\end{tabular} & 8 & 6 & 6 & 5 & 2 & 94 & 69.62 & 2 & \\
\hline & $\begin{array}{l}\text { I am disinterested in allocating time to participate in } \\
\text { (artistic, cultural, or sports) activities. }\end{array}$ & 4 & 6 & 6 & 9 & 4 & 84 & 62.22 & 4 & \\
\hline & $\begin{array}{l}\text { Dividing my time between study and doing activities seems } \\
\text { very difficult. }\end{array}$ & 8 & 6 & 6 & 7 & 2 & 98 & 72.59 & 1 & \\
\hline & I spend most of the time doing beneficial things. & 3 & 8 & 6 & 6 & 4 & 81 & 60 & 5 & \\
\hline \multirow{9}{*}{ 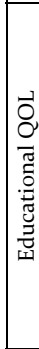 } & I see study tremendously benefits me. & 1 & 4 & 8 & 10 & 4 & 69 & 51.11 & 7 & \multirow{9}{*}{57.52} \\
\hline & $\begin{array}{l}\text { I find it difficult to get scientific counsel from the academic } \\
\text { counselor. }\end{array}$ & 1 & 1 & 11 & 8 & 6 & 64 & 47.40 & 8 & \\
\hline & Some courses are inappropriate for my potentials. & 2 & 6 & 7 & 8 & 4 & 75 & 55.55 & 6 & \\
\hline & I feel I am successful at school. & 5 & 7 & 7 & 4 & 4 & 86 & 63.70 & 3 & \\
\hline & \begin{tabular}{|l} 
I scientifically classify information. \\
\end{tabular} & 2 & 8 & 6 & 10 & 1 & 81 & 60 & 4 & \\
\hline & $\begin{array}{l}\text { I can build new knowledge based on my previous } \\
\text { experience. }\end{array}$ & 8 & 4 & 6 & 5 & 4 & 88 & 65.18 & 1 & \\
\hline & \begin{tabular}{|l} 
I use my knowledge to solve my problems. \\
\end{tabular} & 1 & 4 & 8 & 10 & 4 & 69 & 51.11 & 7 & \\
\hline & I have good relations with my professors. & 6 & 1 & 8 & 10 & 2 & 80 & 59.25 & 5 & \\
\hline & $\begin{array}{l}\text { I plan my academic and professional future using my } \\
\text { knowledge and skills. }\end{array}$ & 5 & 8 & 6 & 4 & 4 & 87 & 64.44 & 2 & \\
\hline \multirow{11}{*}{ 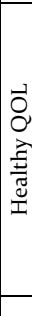 } & I am full of vim and vigor. & 6 & 5 & 1 & 10 & 5 & 78 & 57.77 & 4 & \multirow{10}{*}{56.80} \\
\hline & I tend to have health education. & 5 & 6 & 2 & 8 & 6 & 77 & 57.03 & 5 & \\
\hline & $\begin{array}{ll}\text { I sleep well. } \\
\end{array}$ & 5 & 6 & 5 & 5 & 6 & 80 & 59.25 & 2 & \\
\hline & I feel sick and emaciated. & 3 & 5 & 5 & 9 & 5 & 73 & 54.07 & 6 & \\
\hline & I work out regularly. & 1 & 5 & 5 & 14 & 2 & 70 & 51.85 & 8 & \\
\hline & I take care of myself, whatever my problems. & 5 & 5 & 5 & 7 & 5 & 79 & 58.51 & 3 & \\
\hline & \begin{tabular}{|l|} 
I regularly have medical examinations. \\
\end{tabular} & 2 & 6 & 6 & 7 & 6 & 72 & 53.33 & 7 & \\
\hline & I feel exhausted when I remember being an orphan. & 2 & 4 & 4 & 6 & 11 & 61 & 45.18 & 9 & \\
\hline & I take adequate time for rest. & 3 & 6 & 7 & 8 & 3 & 79 & 58.51 & 3 & \\
\hline & I have a healthy and balanced diet. & 6 & 7 & 5 & 9 & 7 & 98 & 72.59 & 1 & \\
\hline & \multicolumn{6}{|l|}{ Total } & 3373 & $54.31 \%$ & & \\
\hline
\end{tabular}

Table (9) shows that the total score (54.31\%) reflects the low level of the services provided to the orphans at social care homes. While cultural QOL and time management was ranked first with a mean of (63.91\%), psychological QOL was ranked last with a mean of $(44.73 \%)$. 
Family builds a positive QOL, especially the quality of psychological and social life. It provides social status, self-esteem, protection, warmth, and security. Thus, it builds positive trends among the orphans towards themselves, others, and their future. Because of living in social care homes, the orphans suffer difficult psychological circumstances, lack of emotional gratification, and difficult adoption to the environment. They constantly think about their future circumstances, requirements, and lives. Family upbringing and the surrounding circumstances play an important role in raising the level of QOL. Unfortunately, the orphans lack most of the psychological, social, health, and other factors that enhance QOL in social care homes.

QOL is represented in a positive sense of well-being, high levels of satisfaction with self and life in general, and constant pursuit to achieve significant personal goals to independently define life direction and establish ongoing positive social relations. Furthermore, it is associated with the general sense of happiness, enjoying life, tranquility, and psychological reassurance, which the orphans lack at social care homes. The lack of self-esteem relates to the lack of positive reinforcements. Consequently, the orphans' QOL is low. The supervisors' excessive care of the orphans at social care homes to compensate for kindness, affection, and care that they lack maximizes their tension and anxiety, weakens their personalities, reduces their self-dependence, and lowers self-adjustment.

The author claims that the quality of psychological life was ranked last because the satisfaction of substantial needs is the essence of QOL psychologically. The quality of social life ranked fourth due to the orphans' low social belonging, lack of well-being and security, and anxiety. Thus, their social QOL is low. This result is consistent with Ali (2016), Borzak and Shalali (2017), Khamis (2013), Muhammad (2017), Naimat (2016), Salami and Jaloul (2017), and Sabri (2015) who showed low QOL among the orphans. It also agrees with Al-Faqihi (2006), Al-Shareef (2002), Al-Suwaihri (2010), Al-Attas (2013), Al-Thumairy (2011), Barn et al. (2005), Casares et al. (2004), Foster and Williamson (2000), Halima (2013), Ibrahim (2009), Jumaa (2011), Kafi (2012), McMillan (2003), Stein (2006), and Witt and Lessing (2005) that illustrated some characteristics of the orphans, in general, and those at social care homes, in particular. It is consistent with Islih (2000) and Johns and Ramidas (2004) that asserted the importance of family upbringing and the harms associated with parents' loss, as well as their relationship to the low level of the orphans' QOL.

3. To answer the $3^{\text {rd }}$ question, correlation coefficients between the services provided to the orphans at social care homes and their QOL were estimated.

Table (10): Correlation coefficients between the services provided to the orphans at social care homes and their QOL

\begin{tabular}{|l|c|c|c|}
\hline \multirow{2}{*}{ Variables } & \multicolumn{2}{c|}{ QOL } \\
\cline { 2 - 4 } & R Value & Significance level & Significance type \\
\hline Services provided to the orphans at social care homes & $\mathbf{0 . 2 5}$ & o.o1 & Statistically significant \\
\hline
\end{tabular}

Table (10) exhibits a statistically significant correlation between the services provided to the orphans at social care homes and their QOL. In other words, the more services provided to the orphans at care homes are, the higher their QOL becomes. The author argues that this finding is asserted by the results of the first and second questions. The author also attributes it to the fact that the orphans' feeling of the services and care quality at social care homes is a strong indicator of their QOL. The orphans who lack the required care and services do not satisfy their psychological, emotional, social, health, achievement, and recreational needs. Thus, they lack psychological well-being, self-satisfaction, positive social relationships, mental health, quality of emotions, and QOL. This result is consistent with Al-Dahni (2018), Al-Dulaimi and Hassan (2012), Al-Hussainat (2015), Al-Maliki (2011), Bakr (2011), Eid (2018), Fenandez and Rocha (2009), Gamal (2016), Hamed (2018), Kapka et al. (2013), Mahmoud (2016), Mustafa and Youssef (2018), Naimat (2016), Sabri (2015), Salami and Jaloul (2017), and Shokair 
(2010) that showed a direct correlation between QOL and psychological and social characteristics and needs. They also asserted that the concept of QOL has expanded and involved the concepts of mental health, adjustment, optimism, happiness, and life satisfaction with a positive perception.

To answer the $4^{\text {th }}$ question, a proposed program was developed involving the following themes:

A. Description and design of the proposed program

The program aims to improve QOL among orphans at social care homes using guidance strategies and techniques to develop social skills, interact with life situations, and adapt with others and peers. It develops their communication, problem-solving, self-efficacy, selfconfidence, positive thinking, optimism, and self-esteem to improve academic achievement, personal aspects, and time management. The proposed program was developed according to the theoretical framework related to QOL and the relevant literature, including Abu Rasin (2012), Ahmed and Hussein (2009), Al-Birri (2015), Al-Dabour and Zahran (2013), Ali (2012), Aljawalda (2013), Break (2016), Habib (2016), Khalil (2013), Oghnia et al. (2012), Ramadan (2014), and Selim (2015).

B. Fundamentals of the program

- Freedom and responsibility are two sides of the same coin for human existence.

- One feels the value of his/her existence through self-transcendence, as well as positive relations and communication with others.

Will to meaning stimulates the person to search for the value of life.

The frustration of will to meaning among the persons creates an existential vacuum, which denotes the experience of total lack of the essential meaning of the personal existence. Existential vacuum manifests in boredom, indifference, and despair. It causes psychological problems, such as addiction, suicide, and delinquency.

- Suffering and stress are present in all peoples' lives. Their presence does not mean that life is meaningless, but the person can turn them into an accomplishment if he succeeds in realizing the meaning.

- Realizing the meaning signifies the person's self-efficacy. One's awareness of the meaning of life provides him/her with power and motivation, helps survive, and motivates challenging all difficulties.

C. Reviewing the proposed program

The program was reviewed by (6) reviewers specialized in psychological and educational counseling, mental health, and social work to evaluate the program, as well as its goals, sections, and techniques and to suggest modifications.

D. Goals of the program

First: General goal

The program aims to improve QOL and its social, psychological, cultural, academic, health, and educational domains among the orphans at Saudi social care homes.

Second: Special goals

1. Explain QOL, its domains, importance, and impact on the orphans' personality.

2. Encourage the orphans to freely express feelings related to orphanhood experience, selfacceptance, and their reality.

3. Reinforce the orphans' understanding of themselves and encourage them to think about the importance of having personal goals and developing their personalities.

4. Develop the orphans' positive social skills and adjustment with others and peers.

5. Train the orphans in effective communication skills to establish proper interpersonal relationships.

6. Train the orphans to control the environment and have environmental competence.

7. Modify the orphans' perception of events and interaction with life situations.

8. Develop the orphans' self-efficacy, self-concept, and self-confidence.

9. Train the orphans in self-assertiveness to accept themselves and defend their rights in different situations. 
10. Train the orphans in positive self-dialogue to develop positive thinking and self-control.

11. Develop the orphans' ability to face normal crises and difficulties they experience.

12. Train the orphans in problem-solving to properly overcome future problems and anxiety.

13. Train the orphans in relaxation and deep breathing to overcome stressful situations and reduce their stress and anxiety.

14. Modify the orphans' illogical negative thoughts (self-contempt, bad temper, tension, anxiety, depression, social isolation, pessimism, and despair) and replace them with realistic logical ideas.

15. Develop the orphans' skills of time management (goal setting, time management, and organizing leisure activities and rest periods)

16. Train the orphans in the skill of developing an appropriate study schedule through time management, so that they can enhance academic achievement.

17. Explain the concept of fitness, proper nutrition, medical care, exercise, living in a clean environment, their positive impact on the orphans' lives, and how to achieve them.

18. Explain the concept of feeling happy with oneself and others, as well as life satisfaction to achieve social and emotional equilibrium.

E. Significance of the program

- It sheds light on the concept of QOL among orphans at social care homes based on stressful changes and events to improve QOL.

- The program is a practical model appropriate for the orphans because it helps them use the strategies scientifically to achieve social and emotional equilibrium and pass orphanhood experience.

- It provides new methods that help the orphans overcome their problems at social care homes.

F. Necessity of the program

Because the orphans experience psychological suffering, social pressures, problems, and difficult circumstances, it is necessary to develop a program that reduces their suffering. Furthermore, counseling and training services enhance the orphans' QOL. It is substantial to provide the orphans with distinguished services because neglecting these services negatively affects their motivation, achievements, future aspirations, self-esteem, academic achievement, work, mental and physical health, as well as psychological and social adjustment.

G. Services provided by the program

1. Counseling and training services involve training orphans in various strategies to improve their QOL.

2. Educational counseling services involve teaching orphans the method of dialogue, discussion, and scientific thinking when solving problems.

3. Social counseling services are represented in strengthening social relations between the orphans and getting a benefit from each other's experiences.

4. Preventive services are represented in filling the orphans' cognitive deficit concerning the different techniques and methods related to knowledge rebuilding.

5. Recreational services are represented by encouraging orphans to manage time and practice sports and hobbies.

6. Time frame: It is suggested that the program lasts for three months (two sessions per week), except for the last week which involves three sessions. Each session is 90 minutes.

H. Techniques, methods, and aids

Techniques: Symbolic story approach, situational reconstruction, attitudes modification, compensatory self- improvement, integration, facing common behavior, behavior evaluation, responsible behavior, self-control, problem-solving, homework, self-assertiveness, thought stopping, relaxation, seeking support, positive reinforcement, and cognitive restructuring. Methods: Lecture, discussion, modeling, simulation, observation, role-playing, and 
brainstorming.

Aids: Laptop, projector, motivational and educational videos, PowerPoint presentations, cassette tapes, board, and markers.

I. Summary of the sessions' content and the topics of each session:

Table (11): Summary of the sessions' content and topics

\begin{tabular}{|c|c|c|c|}
\hline Topic & Session & Description & Domains of QOL \\
\hline 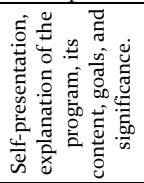 & $1^{\mathrm{st}}$ & $\begin{array}{l}\text { - Welcome the participants and acquaintance between the participants and the author to } \\
\text { build confidence, break the ice, and achieve mutual respect. } \\
\text {-Explain the program, its goals, number of sessions, and assertion of information } \\
\text { confidentiality. } \\
\text {-Agree on the venue of the session and the rules governing the sessions } \\
\text {-Discuss the participants' expectations from the program and promoting positive } \\
\text { expectations. }\end{array}$ & \\
\hline 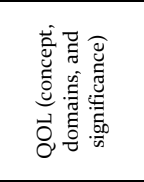 & $2^{\text {nd }}$ & $\begin{array}{l}\text { - Clarify the concept of QOL. } \\
\text { - Clarify the domains of QOL. } \\
\text { - Clarify the consequences of low QOL. } \\
\text { - Introduce the participants to the fundamental practices to improve QOL and its domains. } \\
\text { - Illustrate the importance of QOL. } \\
\text { - Clarify how to obtain an appropriate QOL. } \\
\text { - Clarify the problems and obstacles that cause low QOL. }\end{array}$ & \\
\hline 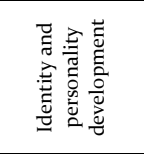 & $3^{\text {rd }} \& 4^{\text {th }}$ & $\begin{array}{l}\text {-Enhance the participants' understanding of themselves. } \\
\text { - Raise The participants' awareness of the characteristics they build and appreciate. } \\
\text { - Introduce the participants to how to think about their dreams. } \\
\text {-Clarify the importance of setting personal goals. } \\
\text {-Introduce the participants to the personal characteristics they seek to develop. } \\
\text {-Explain the importance of developing the participants' character. }\end{array}$ & \multirow{3}{*}{ Social QOL } \\
\hline 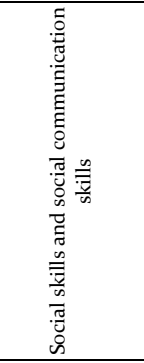 & $\begin{array}{l}5^{\text {th }}, 6^{\text {th, }} \\
\text { and } 7^{\text {th }}\end{array}$ & $\begin{array}{l}\text {-Introduce the participants to the different types of social skills and their importance. } \\
\text {-Introduce the participants to irrational behaviors related to isolation and lack of social skills } \\
\text {-Train the participants in different methods to develop social skills. } \\
\text {-Train the participants in diverse methods to harmonize with others and peers. } \\
\text {-Introduce the participants to patterns of interaction with others (assertive, passive, and } \\
\text { aggressive). } \\
\text {-Show daily life examples on the social skills essential for the orphans. } \\
\text {-Introduce the participants to the concept of social communication and its various elements. } \\
\text {-Train the participants in effective communication skills and their obstacles. } \\
\text {-Train the participants to effectively talk to someone they have a problem with and to express } \\
\text { their positive feelings to others. } \\
\text {-Train the participants in the skills and mechanisms of effective listening. } \\
\text { - Inform the participants of the negative effects of introversion; shame and social isolation, } \\
\text { and the positive effects of establishing equivalent social relations. }\end{array}$ & \\
\hline 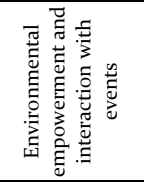 & $\begin{array}{c}8^{\text {th }} \text { and } \\
9^{\text {th }}\end{array}$ & $\begin{array}{l}\text {-Introduce the participants to the concept and importance of environmental empowerment. } \\
\text { - Teach the participants how to use their capabilities to deal with the events they face. } \\
\text {-Train the participants in different methods to interact with life situations. } \\
\text { - Introduce the participants to the importance of adapting to the internal and external } \\
\text { demands and requirements. } \\
\text { - Clarify the relationship between thinking and behavior as well as how thinking affects } \\
\text { behavior. }\end{array}$ & \\
\hline 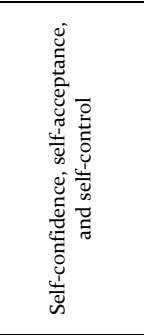 & $\begin{array}{l}10^{\text {th }}, 11^{\text {th }} \\
\text { and } 12^{\text {th }}\end{array}$ & $\begin{array}{l}\text { - Explain the concept of self-confidence. } \\
\text { - Clarify the role of self-confidence in building positive interpersonal relationships. } \\
\text {-Train the participants in different ways of building self-confidence and confidence-based } \\
\text { relations. } \\
\text { - Illustrate the difficulties and problems that result from the lack of self-confidence. } \\
\text { - Explain self-concept, self-acceptance, and discovering their strengths and weaknesses. } \\
\text { - Clarify the importance of a positive self-perception. } \\
\text {-Train the participants in mechanisms of eliminating guilt feelings, self-compassion, and self- } \\
\text { acceptance. } \\
\text {-Train the participants in methods of self-acceptance. } \\
\text { - Introduce the difficulties and problems that result from the lack of self-acceptance. } \\
\text {-Explain the concept of self-control. } \\
\text {-Train the participants in various skills of self-control. }\end{array}$ & \multirow[t]{2}{*}{ Psychological QOL } \\
\hline 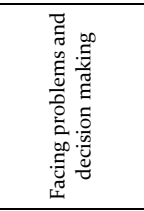 & $\begin{array}{l}13^{\text {th }}, 14^{\text {th }} \\
\text { and } 15^{\text {th }}\end{array}$ & $\begin{array}{l}\text { - Explain the concepts of problem and problem-solving. } \\
\text { - Explain the scientific steps of problem-solving. } \\
\text { - Train the participants on how to define the problem, collect information, accept it, define } \\
\text { alternatives, choose the best alternative, and verify the correctness of the solution. } \\
\text {-Provide the participants with models that help solve problems. } \\
\text { - Introduce the skills of decision-making. } \\
\text { - Explain the fundamentals of decision-making. } \\
\text {-Train the participants in the steps of decision-making. }\end{array}$ & \\
\hline
\end{tabular}




\begin{tabular}{|c|c|c|c|}
\hline Topic & Session & Description & Domains of QOL \\
\hline 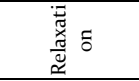 & $16^{\text {th }}$ & $\begin{array}{l}\text {-Clarify the concept, techniques, and importance of relaxation. } \\
\text {-Train the participants in the exercises of relaxation and emotion control. } \\
\text { - Explain the positive effect of relaxation on stress and anxiety. }\end{array}$ & \\
\hline 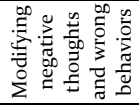 & $\begin{array}{l}17^{\text {th }} \text { and } \\
18^{\text {th }}\end{array}$ & $\begin{array}{l}\text {-Explain the negative thoughts and relevant wrong behaviors. } \\
\text { - Explain the strong connection between misconceptions and the low QOL. } \\
\text {-Train the participants in various mechanisms to overcome negative thoughts and replace } \\
\text { them with positive ones. }\end{array}$ & \\
\hline 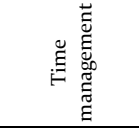 & $19^{\text {th }}$ & $\begin{array}{l}\text {-Explain the concept of time management. } \\
\text {-Explain methods of time waste. } \\
\text { - Train the participants on skills of time management (i.e. setting goals, as well as organizing } \\
\text { and employing leisure activities and rest time). } \\
\text { - Clarify the importance of cultural and entertainment aspects in the participants' life. }\end{array}$ & $\begin{array}{l}\text { Cultural QOL and } \\
\text { time management }\end{array}$ \\
\hline$\frac{\overrightarrow{0}}{\stackrel{0}{0}}$ & $\begin{array}{c}20^{\text {th }} \text { and } \\
21^{\text {st }}\end{array}$ & $\begin{array}{l}\text { - Explain how to increase and reinforce achievement and academic aspect (i.e. knowledge, } \\
\text { abilities and readiness, personal characteristics, patterns of behavior, and wisdom) } \\
\text {-Train the participants in the mechanisms that develop the aforementioned aspects to raise } \\
\text { their academic level. } \\
\text { - Train the participants in the skill of designing appropriate study schedules through time } \\
\text { management to increase their academic achievement. } \\
\text { - Explain how to strengthen the relationship between the participants and their educators to } \\
\text { have higher self-confidence when learning. } \\
\text { - Explain the importance of schoolwork, which is based on desire rather than fear. } \\
\text { - Explain the close relationship between stress, social pressure, as well as academic } \\
\text { adaptation and achievement. }\end{array}$ & Educational QOL \\
\hline 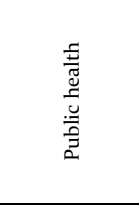 & $\begin{array}{c}22^{\text {nd }} \text { and } \\
23^{\text {rd }}\end{array}$ & $\begin{array}{l}\text {-Explain the concept of public health. } \\
\text { - Explain the proper methods of nutrition. } \\
\text { - Explain the importance of periodic medical care. } \\
\text { - Explain the importance of exercise and its impact on the participants' life satisfaction and } \\
\text { self-confidence. } \\
\text { - Train the participants to breathe comfortably and improve their sleep methods. } \\
\text { - Explain the effects of living in a clean and tidy environment on the participants' QOL. } \\
\text { - Clarify the effects of behavioral disorders on physical health. }\end{array}$ & Healthy QOL \\
\hline 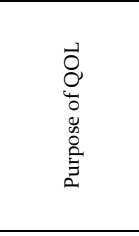 & $24^{\text {th }}$ & $\begin{array}{l}\text { - Encourage the participants to adapt to orphanhood experience optimistically and positively. } \\
\text { - Develop optimism among the participants. } \\
\text {-Identify the effects associated with optimism as a foundation of QOL. } \\
\text {-Identify the negative effects of pessimism and despair on QOL. } \\
\text { - Explain the concept of self-happiness. } \\
\text { - Explain the concept of happiness with others. } \\
\text { - Explain life satisfaction and the purpose of life. } \\
\text { - Clarify the relationship between the above-mentioned concepts and social and emotional } \\
\text { balance. }\end{array}$ & \\
\hline 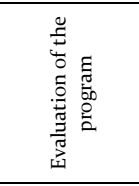 & $25^{\text {th }}$ & $\begin{array}{l}\text { - Connect between the sessions and summarize what was accomplished in them. } \\
\text {-Address the participants' observations and reactions to the program (evaluation of the } \\
\text { program). } \\
\text { - The participants express their feelings towards finalizing the sessions. } \\
\text { - Identify the change in the participants' behavior and perspective for life. } \\
\text { Encourage the participants to apply what they have gained in different life situations. } \\
\text {-Thank the participants for their commitment. }\end{array}$ & \\
\hline
\end{tabular}

\section{Recommendations}

The study recommends adopting the proposed program by decision-makers and specialists in the care and rehabilitation of the orphans to improve their QOL. Training courses and workshops should be delivered to social workers and psychologists to master the different methods and strategies that improve the orphans' QOL. Additionally, specialists of positive psychology may be recruited and educational lectures and seminars are delivered to raise the orphans' awareness of QOL. School and university courses should address the concept of QOL to help students, in general, and the orphans, in particular, identify its standards. The attention of decision-makers and competent bodies should be drawn to the necessity of providing appropriate atmosphere and activities at social care homes to alleviate the severity of their behavioral and emotional disorders, which affect their QOL. Furthermore, social care homes should be supported to care about the orphans, provide their various requirements, and diverse their social, psychological, health, cultural, and educational activities as well as services. Curricula designed for the preparation of educators and social workers at the Faculties of Education, Social Work, and Sociology should address the concepts of QOL to competently deal with the orphans and confront the problems arising from their different circumstances. 


\section{Conclusion}

Orphanhood is a critical stage in the life of orphans who strongly need parental and family care because it has a substantial role in the psychological construction of their present and future personalities as well as their psychological and social adjustment. The orphans see life differently and suffer future anxiety. QOL is an essential goal for every person because it emphasizes the positive personality, life meaning, and the necessity of having a harmonious life, either inside or outside the care house. Consequently, their adjustment improves. When they realize their reality and feel satisfied with it, their mental health improves. Social care homes do their utmost to achieve balance in the child's life, but they do not replace the community's role towards the orphan. Moreover, they minimize pessimism and support the orphans to feel optimistic and have a positive outlook on life.

\section{Acknowledgment}

The researcher thanks the Center for Promising Research in Social Research and Women's Studies at Princess Nourah bint Abdulrahman University for funding this research project.

\section{References}

Abdelhamid, S. (2018). Effectiveness of a proposed program in improving some domains of quality of life for a kindergarten teacher and impact on professional competencies. The Arab Journal of Child Information and Culture, 4, 151-216.

Abu Halawa, M. (2010). Quality of life: Concept and domains. Paper presented at the Annual Scientific Conference of Faculty of Education, Kafrelsheikh University, Egypt.

Abu Hammad, N.(2019). Quality of life and relationship to well-being and self-worth in a sample of students of Prince Sattam Bin Abdulaziz University. Al-Quds Open University Journal for Educational and Psychological Research and Studies, 10 (17), 268-281.

Abu Rasin, M. (2012). Effectiveness of a proposed training program in improving quality of life for the educational diploma students at King Khalid University in Abha. Journal of Psychological Counseling, (30), 167-234.

Abu Shanab, M. (2017). Effectiveness of a behavioral cognitive counseling program in reducing despair and its effect on the quality of life among the students with divorced parents at the Faculty of Home Economics, Menoufia University. Journal of Arab Studies in Education and Psychology, 89, 23-66.

Ahmed, B. (2008). Quality of life scale: A brief form by the World Health Organization. Cairo: The Anglo-Egyptian Bookshop.

Ahmed, S. \& Hussein, W. (2009). Effectiveness of logo counseling in improving QOL among the Faculty of Education students. Journal of Arab Studies in Education and Psychology, 1 (3), 215-242.

Al-Attas, A. (2012). Contentment and psychological loneliness among orphans at social care homes and those living with their families (M.A. thesis). Umm Al-Qura University, Saudi Arabia.

Al-Baz, A. (2012). Developing programs and activities in the orphans' care homes and transforming them into outdoor rehabilitation programs. Riyadh: The National Center for Studies and Social Development.

Al-Birri, M. (2015). Effectiveness of rational, emotional and behavioral counseling program in improving quality of life for the students of Guidance and Counseling Diploma at King Saud University. Journal of Psychological Counseling, 43, 269-301.

Al-Dabour, A. \& Zahran, A. (2013). Effectiveness of rational emotive behavior therapy in improving the quality of life among children with learning disabilities. Journal of Special Education-Zagazig University, (5), 306-345.

Al-Dakhakhni, I. (2007). Effectiveness of a program in developing safety feelings among children deprived of parental care (Ph.D. dissertation). Ain Shams University, Egypt.

Al-Dahni, G. (2018). Quality of life for the students of the Faculty of Education at Yarmouk and Hail Universities: A comparative study. Journal of Educational Sciences, 1 (1), 276-302.

Al-Dulaimi, N. \& Hassan, E. (2012). Self-esteem and relationship to quality of life among the students of University of Babylon. Journal of University of Babylon- Humanities, 20 (4), 1126-1142.

Al-Fangary, H. (2006). Well-being between positive psychology and mental health. Banha: Al-Ikhlas Institution for Printing and Publishing.

Al-Faqihi, M. (2006). Behavioral problems among adolescents deprived of family care in Saudi Arabia (M.A. thesis). Naif Arab University for Security Sciences, Riyadh, Saudi Arabia. 
Al-Hajjaji, E. (2013). Effectiveness of task-based model in treating the problem of identity and social integration of the orphans with special circumstances (M.A. thesis). Imam Muhammad ibn Saud Islamic University, Saudi Arabia.

Al-Hussainat, I. (2015). Quality of the university student's life and relationship to some demographic variables: A study of a sample of Majmaah University students. Educational Journal, 41, 178-233.

Al-Huwairini, R.(2018). Improvement of the quality of life. Al-Jazirah Newspaper. Retrieved from www.aljazirah.com.

Ali, A. (2017).An integrated counseling program to improve quality of life in a sample of kindergarten teachers (Ph.D. dissertation). Faculty of Education, Ain Shams University.

Ali, S. (2016). Developing emotional intelligence and its effect on QOL among orphan adolescents in social care homes in Yemen (Ph.D. dissertation). University of Oran, Algeria.

Ali, W. (2012). Effectiveness of training on assertive behavior in raising the quality of life among university students with hearing impairment. Journal of Educational Sciences, 3 (20), 93-132.

Aljawalda, F. (2013). Effectiveness of an educational program based on the Theory of Mind in improving the quality of life for children with developmental and intellectual disabilities. Journal of Educational Sciences- the University of Jordan, 1 (40), 388-409.

Al-King, A. (2014). Relationship between quality of life and academic motivation from the perspective of positive psychology in a sample of students at Damascus University (Ph.D. dissertation). Damascus University, Syria.

Al-Maliki, H. (2011). Depression, personal meaning, and quality of life in a sample of students at the College of Education, Umm Al-Qura University in the light of some variables. Journal of the Faculty of Education-AlAzhar University, 3 (145), 244-287.

Al-Obaidi A. (2013). Academic procrastination and relationship to quality of life among university students. Journal of Arab Studies in Education and Psychology, 35 (2), 148-171.

Al-Qamsh, M. \& Al-Imam, M. (2006). Children with special needs: Fundamentals of special education. Al Ain: Dar Elqalam.

Al-Rashid, B. \& Al-Dhahyan, S. (2006). Aggressive behavior of children with special needs: An applied study of orphan care institutions in Riyadh. Paper presented at The First Forum of Orphan Care, Riyadh, Saudi Arabia.

Al-Rassi, K. (2006). Ministry of Education's experience in reinforcing learners' quality of life at schools. Paper presented at the Seminar on Psychology and Quality of life, Sultan Qaboos University, Muscat.

Al-Sahli, A. (2011). Effectiveness of social work practice in satisfying some needs of the children deprived of the family (M.A. thesis). King Saud University, Saudi Arabia.

Al-Shareef, M. (2002). Social support and self-esteem as mitigating factors of post-traumatic stress disorder among Palestinian families that suffered loss (Ph.D. dissertation). Zagazig University, Egypt.

Al-Suwaihri, A. (2010). Social and psychosocial problems of the orphans at Mecca charity (M.A. thesis). Umm AlQura University, Saudi Arabia.

Al-Thumairy, A. (2011). Educational stress for the orphan students at social care homes in Riyadh (M.A. thesis). Imam Muhammad ibn Saud Islamic University, Saudi Arabia.

Badr, A.(2019). Counseling program and impact on the quality of life skills for families of children with autism in Qatar. Arab Journal for Scientific Publishing, (11), 84-116.

Bakr, J. (2011). Quality of life and relationship to social belonging and acceptance: A field study on the students of Salahaddin University (Ph.D. dissertation). Salahaddin University, Erbil, Iraq.

Barn, R., Andrew, L. \& Mantovani, N.(2005). Life after care: A study of the experiences of young people from different ethnic groups. York: Joseph Rowntree Foundation.

Baumann, C., Marie-Line, E., Perret, C., Gautier, A., Régat, S., François, J. \& Francis, C. (2011). Health-related quality of life in French adolescents and adults: Norms for the DUKE Health Profile. BMC Public Health, 11, 1-16.

Borzak, K. \& Shalali, A. (2017). Quality of life for orphan adolescents: A field study in Laghouat, Algeria. Journal of Legal and Social Sciences, 1 (4), 77-112.

Boutros, H. (2007). Psychological problems. Amman: Dar Al Massira for Publishing, Printing, and Distribution.

Break, F. (2016). Effectiveness of training on social skills in raising quality of life in a sample of the students of Faculty of Education at Albaha University. Journal of Faculty of Education, 127 (27), 1-34.

Casares, M., Thombs, B., \& Rousseau, C.(2004).The association of single and double orphanhood with symptoms of depression among children and adolescents in Nabmia. European Child E Adolescent Psychiatry, 18(6),369376.

Damiry, M. (2019). Effectiveness of cognitive-behavioral counseling program in improving the quality of life among AlQuds Open University students (M.A. thesis). Al-Quds Open University, Palestine.

Eid, N. (2018). Quality of life scale for adolescents with poor hearing. Journal of Scientific Research in Education, 19, 59-78. 
Fenandez, M. \& Rocha, V. (2009). Impact of the psychosocial aspects of work on the quality of life of teacher. Revista Brasileire de Psiquiatria, 31 (1), 15-20.

Foster, G. and Williamson, J.(200o). A review of current literature on the impact of HIV/AIDS in children SubSaharan Africa. AIDS, 14(3), $275^{-284}$.

Gamal, N. (2016). Quality of life and its relationship to counseling needs among high school students (M.A. thesis). Damascus University, Syria.

Habib, S. (2016). Effectiveness of a training program in improving the quality of academic life for the gifted students. Journal of Special Education, 16 (4), 219-263.

Halima, Q. (2013). The socio-psychological adjustment of the orphan child: Studies in childhood. Al-Basira Center for Research, Consulting, and Educational Services, (4), 129-156.

Hamed, W. (2018). A study of psychological stress and relationship to quality of life among faculty members at King Saud University. International Journal of Educational Psychological Studies, 3 (1), 25- 48.

Harman, J., Childs, G. \& Kelleher, K.(200o). Mental care utilization and expenditures by children in foster care. Archives of Pediatrics and Adolescent Medicine,154, 1114-1117.

Ibrahim, B. (2009). Effectiveness of a program in developing the orphan's emotional intelligence and psychological adjustment in early childhood (Ph.D. dissertation). Cairo University, Egypt.

Islih, K. (200o). Psychological adjustment among orphans: A field study of the martyrs in Gaza governorates (M.A. thesis). Al-Aqsa University, Palestine.

Johns, G. \& Ramidas, K. (2004).Untying the knot: Ideal and reality in Asian marriage. Singapore: Asia Research Institute.

Jumaa, A. (2011). Sports and physical education programs at orphans' care homes in Jeddah. Al-Qadisiya Journal for the Sciences of Physical Education, 11 (3), 323-348.

Kafi, H. (2012). Psychological security and relationship to expectations of success and failure in a sample of orphans in Mecca (M.A. thesis). Umm Al-Qura University, Saudi Arabia.

Kapka, S., Baumann, C., Anota, A., \& Buron, G. (2013). The relationship between traits, optimism, anxiety and healthrelated quality of life in patients hospitalized for chronic diseases. Health and Quality Life Outcomes, 11(1) 112.

Khalil, M. (2013). Effectiveness of multidimensional counseling program in improving the quality of life for abused children (M.A. thesis). Zagazig University, Egypt.

Khamis, L.(2013). Quality of life and relationship to some social behavior characteristics in a sample of the orphans with or without parentage in Bahrain (M.A. thesis). The University of Bahrain, Bahrain.

Lwasaki, Y. (2007).Leisure and quality of life in an international and multicultural context: What are major pathways linking leisure to quality of life. Social Indicative Research, 82 (2), 233-264.

Mahmoud, H. \& Al-Jammali, F. (2010). Effectiveness of the perceived self and impact on quality of life among high and low university achievers. Journal of American Arabic Academy for Science and Technology, 1 (1), 61-115.

Mahmoud, M. (2016). Psychological hardiness and relationship to quality of life among the students of King Saud University. Journal of Arab Studies in Education and Psychology, 74, 355-384.

Mansi, M. \& Kadhim, A. (2006). Quality of life scale for university students. Paper presented at Psychology and Quality of life Seminar, Sultan Qaboos University, Oman.

Mansi, M. (2010). Development and validation of quality of life scale among university students in the Sultanate of Oman. Journal of American Arab Academy for Science and Technology, 1(1), 41-60.

Mashri, S. (2014). Quality of life from the perspective of positive psychology: An analytical Study. Journal of Social Studies and Research, 8, 215-237.

McMillan, J. (2003). Development of the level of stability index for children (LSIC): Determining indicators of emotional and behavioral stability of children(Ph.D. dissertation). Florida State University, Tallahassee, Florida.

Mousa, W. (2016). Effectiveness of a counseling program based on stress management strategies in improving the quality of life of divorced students at Al-Aqsa University (M.A. thesis). Al-Aqsa University, Palestine.

Mustafa, B. \& Youssef, J. (2018. Level of quality of life among the students of Msila University in Algeria. AlJamie Journal in Psychological Studies and Educational Sciences, 8, 413-431.

Muhammad, E. (2017). Effectiveness of logotherapy program in developing the quality of life in a sample of orphan adolescents (M.A. thesis). Ain Shams University, Egypt.

Naimat, M. (2016). Psychological stress in a sample of orphans in Aqaba governorate and relationship to psychological hardiness and quality of life (M.A. thesis). Mutah University, Jordan.

Obaid, A. (2013). Emotional intelligence and relationship to self-effectiveness among the orphans of SOS village (M.A. thesis). The Islamic University of Gaza, Palestine.

Oghnia, S., Al-Alfi, E., \& Abdelhadi, I.(2012). A counseling program to improve the quality of life for the students of 
the University of Libya. Journal of Scientific Research in Arts-Ain Shams University, 13 (1), 81-110.

Omar, S. (2008). Adoption of the Scandinavian approach to improve the quality of life of hearing and visually impaired persons. Paper presented at the Sixth International Conference on Rehabilitation of People with Special Needs "Reality Monitoring and Future Prospecting", Cairo University, Egypt.

Pekmezovic,T., Popovic, A.,Tepavcevic,D., Gazibara,T., \& Paunic,M. (2011).Factors associated with health-related quality of life among Belgrade University students. Quality Life Research, 20 (3), 391-397.

Ramadan, H. (2014). Effectiveness of a counseling program in improving quality of life using multi-component therapeutic interventions of positive psychology. Journal of Arab Studies in Education and Psychology, 54, 251280.

Sabri, M. (2015). The perceived quality of life among the orphans of unknown parentage at social care homes and its relationship to depression and stress. Retrieved from www.researchgate.net 'publication> 3 .

Salami, D. \& Jaloul, A. (2017). The orphans' quality of life and its achievement. Qabas Journal of Humanities and Social Studies, 2 (2), 41-6o.

Salem, S.(2001). Happiness and relationship to some psychological variables: A correlational developmental and comparative study (M.A. thesis). Cairo University, Egypt.

Selim, S. (2015). Effectiveness of behavioral counseling program in developing social competence and improving quality of life for students with learning disabilities. Journal of Special Education and Rehabilitation, 8 (2), 4886.

Seligman, M.(2002).Positive psychology, positive prevention, and positive therapy. In C. Snyder \& S. Lopez (Eds.), Handbook of positive psychology (pp. 3-9). Oxford: Oxford University Press.

Shokair, Z. (2010). Quality of life and sleep disorders among young people. Paper presented at the Second Regional Conference of Psychology, Egyptian Psychologists Association, Egypt.

Stein, H.(2006). Maltreatment, attachment, and resilience in the orphans of Duplessis. Psychiatry,69 (4), 306-313.

Taylor, M. \&Carlson, S. (2004).The characteristics and correlates of fantasy in school-age children: Imaginary companions, impersonation, and social understanding. Developmental Psychology, 4, 1173-1187.

UNICEF.(2004).The framework for the protection, care and support of the orphans and vulnerable children living in a world with HIV and AIDS. USA: UNICEF.

UNICEF (2006). The children's status in the world (excluded and invisible). USA: UNICEF.

Witt, M. \& Lessing, A. (2005).Educator's views on the needs and support of HIV/AIDS orphans in their psychosocial development. Journal of Child and Adolescent Mental Health, 17 (1), 13-22.

Zidan, A. (2015). Effectiveness of religious and group psychological counseling in developing the quality of life among high achievers. Journal of Special Education, 4 (13), 185-240. 